\title{
Romanian Allergology in the actual European context
}

\author{
POLLIANA MIHAELA LERU ${ }^{1}$, DIANA MIHAELA DELEANU ${ }^{2}$ \\ ${ }^{1}$ UMF "Carol Davila" Bucharest \\ ${ }^{2}$ UMF "Iuliu Hațieganu” Cluj-Napoca
}

\begin{abstract}
Allergic diseases represent an important health problem in the most of developed countries, due to continuous increasing prevalence, with significant individual and social consequences. Allergic diseases may raise serious problems in clinical practice, derived from complexity of clinical forms and mechanisms and from rising incidence of severe cases, with high fatality risk. Taking into consideration the dramatic increase of all allergies forms during the last decades, they are considered a real "epidemic" of the $\mathrm{XXI}^{\text {st }}$ century, being classified by the World Health Organization as the fourth most frequent chronic diseases. The European authorities pay more attention to allergic diseases in last years and discuss the actual situation of the allergology specialty in different countries, with the aim of harmonization and improvement of medical assistance in this field. The aim of this paper is presentation of some relevant aspects of allergology specialty and practice in our country in the actual European context, mainly unmet needs and difficulties, taking into consideration recommendations and priorities recently issued by European authorities. We hope for a better recognition of the specialty and improved interdisciplinary collaboration.
\end{abstract}

Key words: allergology, allergic diseases, European context, specialty.

\section{INTRODUCTION}

Allergic diseases represent an important heath problem in most of developed countries, due to continuous increasing prevalence, with significant individual and social consequences. Allergic diseases may raise serious problems in clinical practice, derived from the complexity of clinical forms and mechanisms and from the rising incidence of severe cases, with high fatality risk. Taking into consideration the dramatic increase of all allergies forms during the last decades, they are considered a real "epidemic" of the XXI century, being classified by the World Health Organization as the fourth most frequent chronic diseases [1].

The prevalence of allergic diseases is estimated to be up to $30 \%$ of population and the continuation of this epidemiological trend may lead to an increase of prevalence to almost $50 \%$ of population during the next 15 years [2]. The most frequent allergies are respiratory, with allergic rhinitis on the first place, affecting more than 25\% Europeans, followed by bronchial asthma, with $20 \%$ prevalence and skin allergies, with $15 \%$ prevalence [3]. About $20 \%$ of allergies may be severe, with high fatality risk, like anaphylaxis and acute asthma, but also some drug-induced or idiopathic allergies, with complex mechanism, not fully understood. Despite of the great progress in research into the causes and treatment of allergies during the last decades, there are still many problems to be solved in this field.
Recently, the European authorities have paid more attention to allergic diseases, following the lobby of professional societies, who discuss the status of allergology as a specialty in different countries and the need to have a homogeneous and better assistance of allergic patients.

Epidemiologic studies performed during the last decades show significant changes regarding the frequency and importance of diseases in general pathology and consequently the need to adapt the medical university and postgraduated training, as well as to evaluate the competences and position of different specialties in medical practice. The increased migration of doctors between European countries requires harmonization of medical training, curricula and name for all specialties, including allergology. Another aspect is the importance of interdisciplinary collaboration and implication of as many specialists from our country in international research studies, at the highest scientific standard in all medical fields, including allergology and clinical immunology.

\section{THE PROBLEM OF ALLERGIC DISEASES IN EUROPE}

The scientific societies have intensified their lobby activity in front of European authorities, aiming to draw attention to the burden and importance of allergic diseases and to allergology as a medical 
specialty. There are many unmet clinical needs and millions of patients are undertreated or not treated with the most appropriate methods and the development of innovative therapies are slow compared to other medical fields.

A Written Declaration on Recognizing the Burden of Allergic Diseases was submitted by the European Academy of Allergology and Clinical Immunology (EAACI) in 2013 at the European Parliament. This was supported by a total of 178 members, being the second highest score of a Written declaration concerning a public health matter and an excellent tool to raise awareness on allergic diseases within the European Parliament. The EAACI allergies diagnostic test event was also organized in the European Parliament in Brussels, in January 2014 and allowed 350 people to be examined for sensitization to common allergens. $47 \%$ tested persons were positive and this result confirmed the importance of allergy diagnosis in general exposed population, before being symptomatic [4].

In March 2012 the EAACI Interest Group on Aerobiology and Air Pollution organized a Workshop called "Allergies in a changing Environment in Europe", attended by World Health Organization representatives, those of research programmes and of patients associations. The main messages were: multifactorial ethiopathogeny of allergic diseases, increased prevalence of allergies in a continuous changing environment, the need for increased financial allocation dedicated to research in this field, in order to get better understanding of mechanisms, identification and stop the causes.

\section{ALLERGOLOGY AS MEDICAL SPECIALTY IN EUROPE}

The dramatic increase of allergic diseases worldwide, but mainly in developed countries, has pointed out the necessity to revise the status of allergology as specialty in different European countries and to take into consideration some changes in order to ameliorate the epidemiologic trend, as well as to increase satisfaction of both patients and doctors. The Union of European Medical Specialists (UEMS) was created in 2010 and the Allergology Section and Board has recently defined the focus of the specialty and requirements for training and education, starting from the need of its harmonization in Europe. The position paper published in Allergy in 2013 called "Allergology in Europe- the blueprint", was initially elaborated by the Dutch Allergology Society and further agreed by EAACI [5].

The main objectives are: increased importance of allergology as specialty in Europe, improvement of medical assistance of allergic patients, harmonization of specialty training in all countries. The document contains suggestions regarding the name of the speciality, training duration and curricula, the allergist competences and collaboration with other specialists, organization of allergy centers and of national allergy network.

Table 1

Main aspects of Allergology speciality in Europe

\begin{tabular}{|l|l|}
\hline Name & Allergology or Allergology and Clinical Immunology \\
\hline Full specialty & 12 European countries (ex.Romania, Italy, Spain, Greece, Portugal, England, Switzerland ) \\
\hline Sub-specialty & 6 countries (ex.France, Germany) \\
\hline Pediatric allergology & Specialty or Sub-specialty or not recognized \\
\hline Training duration & 4-5 years as full specialty or 2-3 years as sub-specialty \\
\hline Final evaluation & $\begin{array}{l}\text { National or European (EBAACI - European Board of Accreditation in Allergology \& Clinical } \\
\text { Immunology, 2010) }\end{array}$ \\
\hline Practice place & Hospitals or Outpatient or Combined \\
\hline Mean number of specialists & EU =1/50.000 inhabitans, USA =1/75.000 inhabitans \\
\hline $\begin{array}{l}\text { Number of specialists in } \\
\text { Romania }\end{array}$ & Max. 1/125.000 inhabitants \\
\hline
\end{tabular}

In the United States of America allergology has been full specialty, changed in sub-specialty and actually most of specialists and officials agree upon the need to become again full specialty, due to increased prevalence of allergic diseases.

The name of the specialty also differs: in some countries it is Allergology, in others, including Romania, is Allergology and clinical immunology.
In some countries pediatric allergology is also recognized as full specialty or sub-specialty.

The duration of the specialty training varies from 2-3 years in case of sub-specialty, usually based on internal medicine or pediatry or an organbased specialty like pneumology, dermatology, ORL. In case of full specialty, the duration of training has been five years and was recently 
reduced to four years in many countries, including Romania. The final evaluation is national and since 2010 the European Board for Accreditation in Allergology \&Clinical Immunology (EBAACI) has introduced the European evaluation.

\section{SPECIFIC TASKS FOR ALLERGY/CLINICAL IMMUNOLOGY SPECIALIST}

They are complex and have recently changed under the pressure of significant progress in this field.

The main tasks of allergy specialist are all organ or multiorgan diseases with a possible immun- allergic mechanism. He has to be informed about the very dynamic development of knowledge regarding immunologic mechanisms, diagnostic methods and new therapies, like molecular allergology, component-resolved diagnostic. Due to increased complexity of environmental factors, allergists have to be able to investigate the role of climate changes, air pollution and health impact of different other risk factors of allergies. Other activities of allergists are: implication in research projects, epidemiologic studies to evaluate the trend of diseases, educational programmes for patients, families and other specialists, lobby to national and international authorities, occupational medicine.

Table 2

Main tasks of allergy specialists

\begin{tabular}{|l|l|}
\hline Multiorgan diseases & Diseases with immune-allergic mechanism \\
\hline Allergies & Food allergies, drug allergies, insect venom \\
\hline Acute diseases & Respiratory, cutaneous, anaphylactic reaction, angioedema, etc. \\
\hline $\begin{array}{l}\text { Immunotherapy or } \\
\text { desensitization }\end{array}$ & To respiratory or food allergies \\
\hline $\begin{array}{l}\text { Immun-mediated systemic } \\
\text { diseases }\end{array}$ & $\begin{array}{l}\text { Collagen-vascular diseases, autoinflammatory syndromes, hypersensitisation pneumonities, immuno- } \\
\text { deficiencies }\end{array}$ \\
\hline Hematologic disorders & Hypereosinophilic and hyper IgE syndromes \\
\hline Other activities & $\begin{array}{l}\text { Research project, epidemiologic studies, educational programmes for patients and other health } \\
\text { professionals }\end{array}$ \\
\hline Occupational allergies & Allergenic substances at work and Environment evaluation (pollens, molds, etc.) \\
\hline Skin disorders & Urticaria, contact dermatitis, atopic dermatitis, other skin disorders \\
\hline Recurrent infections & Hereditary angioedema, mastocytosis, broncho-pulmonary aspergillosis \\
\hline Rare diseases & \\
\hline
\end{tabular}

\section{DIFFICULTIES IN ACTUAL} ALLERGOLOGY PRACTICE

- Increased number of allergic patients addressed to specialists, some of them could have been solved in primary care.

- Chronic or recurrent natural evolution of allergies, lack or limitation of validated diagnostic and therapeutic methods in many cases, leading to frustration of both patients and doctors.

- Obligation to monitor severe cases, with fatality potential or during in vivo investigations, like immunotherapy, due to impredictable evolution and risk of complications.

- Inappropriate evaluation of allergic diseases in hospitalised cases in the International Coding of Diseases (ICD10), leading to misclassification, general underestimation and low visibility of these pathologic conditions (very low complexity indexICM).

- The consequences are for medical practice, but also for epidemiologic studies and national health surveys, due to diagnostic confusions.
- Differences between status of specialty allergology and training curricula in European countries may lead to confusion and unclear delimitation of competences and obligations of specialists involved in medical care of allergic diseases, including application of guidelines and recommendations of international experts.

- Intensive promotion of various complementary or alternative diagnostic and treatment methods in the media, not scientifically validated in most cases or even harmful.

- Insufficient number of specialists, inadequate distribution between countries and regions leading to inequities regarding patients access to specialist assistance.

\section{RECOMMENDATIONS REGARDING SPECIALTY TRAINING}

According to the evaluation performed by the Union of European Medical Specialists (UEMS) and EAACI, there are four types of allergology training in Europe [6]: 
- Type A: full specialty, after national exam, according to national or international curricula.

This type offers more responsability to allergist, the obligation and authority to take care of more complex multiorganic diseases, to coordinate the interdisciplinary team and have other tasks, like educational programs for other specialists.

- Type B: sub-specialty, after a basic specialty like internal medicine or pediatry or an organ-based specialty, like pneumology, ORL or dermatology. The advantages of this type are: a bigger professional group, avoids isolation of allergists, facilitates a better integration with other specialists and more patients to take care of, broader spectrum of diseases, but may lead to superposition with other specialists (ex. rheumatologists). Types C and $\mathrm{D}$ are combinations of the firsts two.

European authorities (EAACI-UEMS) advocates the status of allergology as full specialty in most (all) European countries, aiming to harmonize the training and medical assistance in this field, to avoid gaps between assistance given to different populations and to facilitate free circulation of doctors and international collaboration.

The second proposal refers to training requirements as follows: the duration of training in allergology and clinical immunology should be minimum 5 years, with minimum two years common trunk internal medicine or pediatry, followed by 3-6 months complementary pediatry or internal medicine, 2 years allergology and clinical immunology in accredited institutions, 3 months immunology laboratory, 3 months an organ-based specialty (ORL, pneumology and/or dermatology), optional training - clinical pharmacology, epidemiology, occupational or environmental medicine [5]. It is also recommended to national allergology societies to sustain introduction of allergology education in the university curricula.

\section{ARGUMENTS IN FAVOR OF ALLERGOLOGY} AS FULL SPECIALTY

- increased burden of allergic diseases

- the need of more coherent efforts to stop the epidemiology trend

- the chronic long-life evolution of allergies, with very early onset in childhood

- the unmet needs regarding diagnostic and treatment, unknown causes

- general dissatisfaction of patients and doctors research

- need for more education, prevention and

- need to improve particular methods, like molecular allergology, immunotherapy, desensitisation.

Interdisciplinary collaboration in allergic pathology should be standardized, according to current international guidelines and cost-efficient, based on a clear statement of competences and obligations of each specialist. It is therefore important that all doctors have a basic knowledge in this field.

European Academy of Allergology and Clinical Immunology (EAACI) recommends the development of Allergy Centers in all European countries, with an efficient regional distribution. The optimal location for an Allergy Center is in university or large regional hospitals, with all relevant specialties adequately represented. The optimal number of Allergy Centers is 1/750.000 inhabitants. The center may offer diagnostic tests and medical advise to more complex patients, coordinate the National Allergy Network, has an academic role in training allergists and other specialists, coordinate national health programmes, epidemiologic studies, clinical research and stimulate the specialty development.

\section{Allergology center}

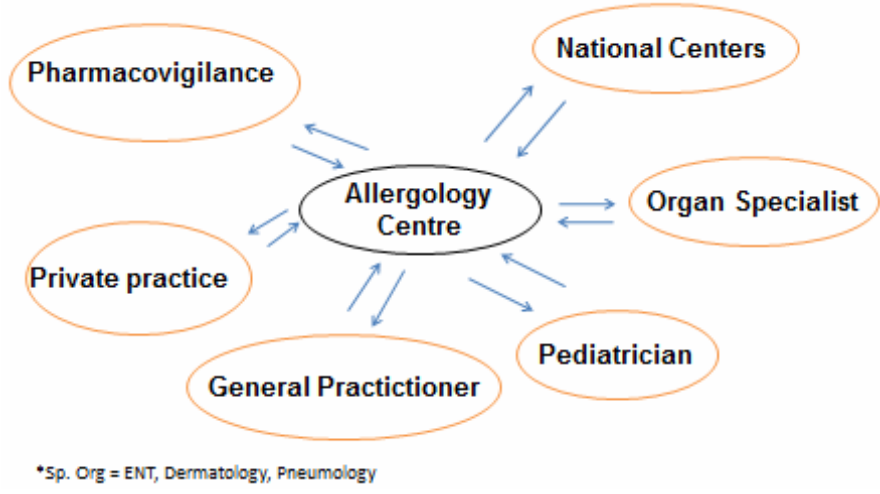

Fig. 1. Role and activities of Allergy Centers (EAACI recommendations). 
In Romania there are maximum ten clinic allergology departments in Bucharest and other university centers (Cluj, Iaşi, Timişoara, Târgu Mureş, Braşov), most of them with very few capacities and specialists, representing at least
2.5-3 times less than the required number of allergy centers in Europe.

The recommended specialists number in European countries is generally one for 50.000 inhabitants, while in the USA it is $1 / 75.000$ inhabitants [7].

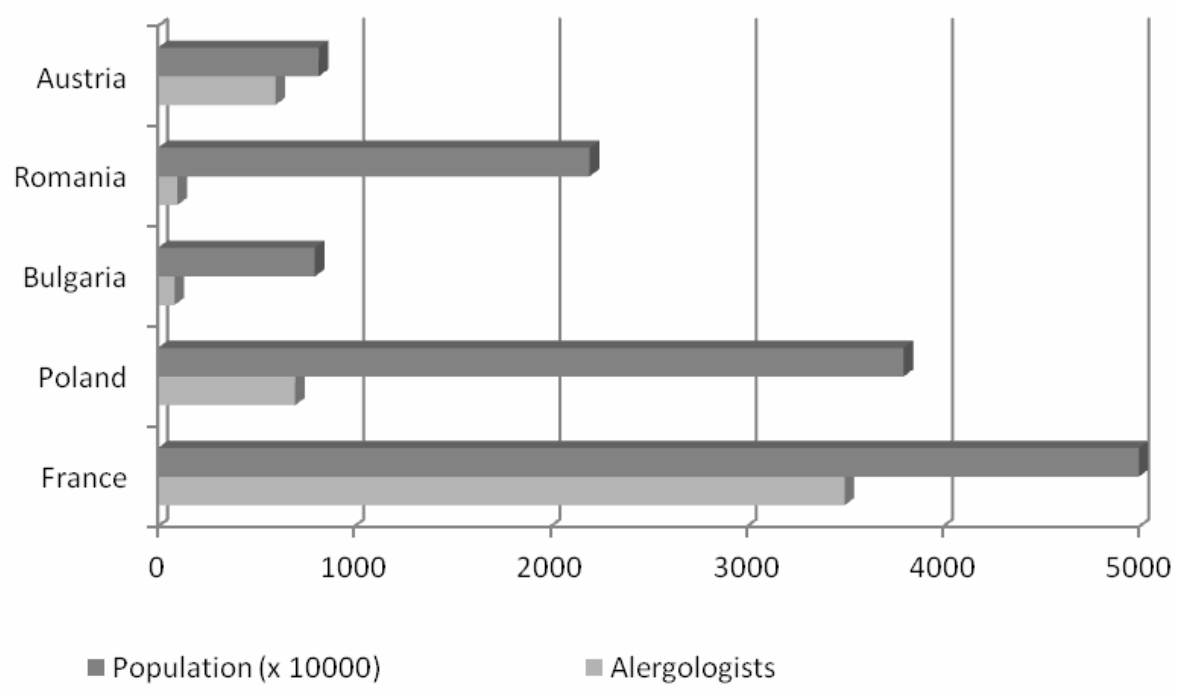

Fig. 2. Number of Allergists in some European countries.

Some examples from other European countries: in Poland there are 700 active allergists for a population of 38 millions (1/54.000 inhabitants), in Austria there are 600 allergists for 8,2 mill. inhabitants (1/13.600 inhabitants), in France there are at least 1700 allergists (480 exclusive plus 1200 with allergology competence or capacity) for 57 mil. inhabitants (1/33.500 inhabitants). In Romania there are maximum 150 allergists for a population of 19 millions, meaning about 1/125.000 inhabitants, therefore again 2.5 times less than the mean number of allergists in European countries.

Pediatric Allergology has a different status from one country to another, being either full specialty or sub-specialty or not recognized. The importance of pediatric allergology has been increasing during the last two decades, taking into consideration the onset of allergies at the beginning of life, the increased prevalence of allergies in children, with new and severe forms. The European Society of Pediatric Allergology and Clinical Immunology (ESPACI) was created in 1990, when the first number of its journal Pediatric Allergy and Immunology (PAI) was published. The role of pediatric allergology is important for reversing the epidemiologic trend of allergies. The main interest areas are: understanding the early mechanisms of allergic sensitization, application of coherent strategies for primary and secondary prevention, evaluation of diagnostic and therapeutic tests validity at the beginning of the allergic march, efficiency and safety of dietary and environmental control in childhood, family education [8].

\section{ROLE OF INTERNATIONAL ALLERGOLOGY SOCIETIES}

European Academy of Allergology and Clinical Immunology (EAACI) is the most important European Allergology society and one of the most active in the world. It was created in 1957, has now almost 8000 members from 121 countries, collaborates with 47 national societies and has a remarkable development during last years. Besides organization of annual congress, schools, workshops, symposia and publication of prestigious medical journals (Allergy, PAI, Clinical Translational Allergy), EAACI has worked on and issued many guidelines, position papers and consensus documents on the most relevant topics in allergic pathology and it has also an intensive lobby activity in front of European authorities.

The World Allergy Organization (WAO) was created in 1951 and collaborates with more than 95 national and regional societies.

Romanian Society of Allergology and Clinical Immunology (SRAIC) was created in 1990 by 
Prof. Jeana Rodica Radu, with 40 members at the beginning and in 1996 allergology and clinical immunology was recognized as full specialty in Romania.

At present SRAIC has about 135 subscribing members, it is internationally recognized and active, collaborates with EAACI, WAO and many other scientific societies in the field of allergology and clinical immunology. SRAIC organizes an annual conference and a congress at each four years, workshops, summer schools, symposia and is represented in the board of EAACI,WAO and Continuous Medical Education Committee.

\section{GLOBAL CLASSIFICATION AND CODING OF ALLERGIC DISEASES IN MEDICAL PRACTICE}

One of the most important recent initiatives of EAACI and WAO towards increased attention to allergology and allergic diseases in medical practice was publication of a survey regarding coding of these diseases, followed by recommendations to its update and improvement in the next international coding - ICD11 [9].

It was proved that allergic diseases are not adequately coded in the actual ICD-10, resulting in statistic errors, misclassification and low visibility of these pathologic conditions. The most important consequences are underdiagnosis and underestimation of severity of allergies and long term errors in epidemiologic studies and official statistics. This conclusion supports the need to update the current classification of allergic diseases and it can be useful to the World Health Organization (WHO) in improving the clinical utility of classification and its acceptability for the next revised ICD-11.

\section{PROPOSALS REGARDING DEVELOPMENT OF ALLERGOLOGY AND CLINICAL IMMUNOLOGY}

We consider that Allergology and Clinical Immunology is an important medical field and specialty that has to be developed and consolidated, in order to face the dramatic increase of prevalence and complexity of allergic diseases. Some actions have to be undertaken:

- Introduction of allergology and clinical immunology in the medical university curricula and correlation of specialty training with current European recommendations

- Development of Allergy Centers and National Allergy network, with regional distribution, development of pediatric allergology and increase of the number of specialists

- Improvement of interdisciplinary collaboration, better delimitation of competences of each specialty involved in the medical care of allergic patients

- More coherent efforts for a better codification of allergic diseases of hospitalized patients in the next coding ICD11 and improved ICM

- Implementation of a National Registry of allergic diseases, implication of Romanian specialists in research national and international projects associations

- Stimulation and collaboration with patients

- Increased efforts for recognition of importance of some rare diseases and reimbursement of specific investigations and medications (like hereditary angioedema, mastocytosis, immunodeficiencies).

Bolile alergice reprezintă o importantă problemă de sănătate, în special în țările dezvoltate, atât prin prevalența în creştere, cât şi prin consecințele sociale şi individuale importante. Problematica bolilor alergice este remarcabilă în practica medicală, prin complexitatea formelor clinice şi a mecanismelor patogenice, dar mai ales prin formele severe cu risc mare de deces. Având în vedere creşterea dramatică a tuturor formelor de alergii în ultimele două decenii, acestea sunt considerate o adevărată ,epidemie” a secolului al XXI-lea, fiind clasificate de către Organizația Mondială a Sănătății (OMS) pe locul patru din punct de vedere al frecvenței bolilor cronice. Autoritățile europene acordă o atenție crescută bolilor alergice în ultimii ani, iar organizațiile medicale reprezentative discută despre statutul alergologiei ca specialitate în diferite țări, cu scopul uniformizării acestuia şi al îmbunătățirii asistenței de specialitate. Articolul de față își propune prezentarea unor aspecte relevante ale alergologiei ca specialitate şi practică medicală în țara noastră, în contextul european actual, ținând cont de 
recomandările şi prioritățile conturate recent de către autoritățile medicale europene. Sperăm într-o mai bună vizibilitate şi recunoaştere a specialității alergologie şi imunologie clinică şi îmbunătățirea colaborărilor interdisciplinare.

Cuvinte cheie: alergologie, boli alergice, context european, specialitate.

Corresponding author: Leru Polliana Mihaela,

UMF "Carol Davila"

E-mail: polianaleru@yahoo.com

The authors declare no conflict of interest.

\section{REFERENCES}

1. PAWANKAR R, CANONICA GW, HOLGATE ST, LOCKEY RF, editors. WAO White Book on Allergy; World Allergy Organization. Philadelphia: Lippincott, 2011.

2. RING J, AKDIS C, BEHRENDT H, LAUENER RP, SCHAPPI G, AKDIS M et al. Davos declaration: allergy as a global problem. Allergy 2012;67:141-143.

3. ASHER MI, MONTEFORT S, BJORKSTEN B, LAI CK, STRACHAN DP et al. Worldwide time-trends in the prevalence of symptoms of asthma, allergic rhinoconjunctivitis and eczema in childhood: ISAAC Phases one and three repeat multicountry cross-sectional surveys. Lancet, 2006; 368:733-743.

4. MURARO A, PAPADOPOULOS NG. Skin prick test at the European Parliament and Written Declaration on Recognising the Burden of Allergic Diseases. EAACI 2014; Newsletter 34;1.

5. DE MONCHY JG, DEMOLY P, AKDIS CA, CARDONA V, PAPADOPOULOS NG, SCHMID-GRENDELMEIER P, GAYRAUD J. Allergology in Europe, the blueprint. Position paper. Allergy 2013; 68:1211-1218.

6. CHIVATO T, VALOVIRTA E, DAHL R, DE MONCHY J, BLOCH THOMSEN A, PALKONEN S, et al. Allergy, Living and Learning: Diagnosis and treatment of allergic respiratory diseases in Europe. J Investig Allergol Clin Immunol, 2012; 22(3):168-179.

7. MARSHALL G. The status of US allergy/immunology physicians in the $21^{\text {st }}$ century. J Allergy Clin Immunol 2007; 119:802-807.

8. WAHN U. The life of PAI. Pediatr Allergy Immunol 2014; 25:2-3.

9. DEMOLY P,TANNO LK, AKDIS CA, PAWANKAR R, PAPADOPOULOS NG et al. Global classification and coding of hypersensitivity diseases. An EAACI-WAO survey, strategic paper and review. Allergy 2014; 69(5):559-570. 